\author{
Ewa Malchrowicz-Mośko \\ https://orcid.org/0000-0002-7676-1477 \\ Poznan University of Physical Education \\ Department of Sports Tourism \\ malchrowicz@awf.poznan.pl \\ Wil Munsters \\ Center for Cultural Tourism Research \\ Zuyd University of Applied Sciences \\ wil.munsters@zuyd.nl \\ Paulina Korzeniewska-Nowakowska \\ (iD) https://orcid.org/0000-0001-7878-7956 \\ University of Zielona Gora \\ Institute of Modern Languages \\ paulinakorzeniewska@gmail.com \\ François Gravelle \\ Ottava University \\ School of Human Kinetics \\ fgravel@uottawa.ca
}

\title{
CONTROVERSIAL ANIMAL TOURISM CONSIDERED FROM A CULTURAL PERSPECTIVE
}

\begin{abstract}
An aspect of controversial animal tourism that has received little attention is its relationship with cultural tourism. The article presents a categorization of cultural tourism, and sports attractions and events related to the abuse of animals. It shows how tourists, driven by cultural omnivorousness and the wish to stand out from the crowd, eagerly enjoy controversial forms of animal tourism on their travel. In order to avoid the pitfall of western ethnocentrism ending in accusations of barbarism, the issue is also reflected on from an intercultural point of view, which helps to understand that local communities have different attitudes to animals and their wellbeing. In addition, a historical overview shows that 'animal friendliness' does not have a long tradition in western thinking about the human-animal relationship and is only of recent date. Sustainable solutions for controversial animal tourism have to be found by raising tourists' awareness by means of information and education.
\end{abstract}

Keywords: controversial animal tourism, animal attractions and events, cultural tourism, sports tourism, cultural omnivorousness, ethnocentrism, responsible tourism, sustainable tourism.

\section{INTRODUCTION}

The so-called postmodern tourist looks increasingly for sensational, emotional and often controversial forms of travelling including sex tourism, drug tourism, stagparty tourism, slum tourism, ghetto tourism, dark tourism, extreme tourism, war tourism and shock tourism. The constant search for new, extraordinary and shocking holiday adventures is typical of tourists living in postmodern consumer-centred societies dominated by sensation seeking (Pine and Gilmore, 2011; Schulze, 1992). Another reason why controversial tourism is developing in a very dynamic way can be found in the eagerness of individuals to distinguish themselves from the mass and to impress others. It is true that many forms of tourism can be controversial, including traditional sightseeing, which may lead to the overexploitation and destruction of frequently visited sites, or museum tourism focusing on shocking exhibitions. However, in this context, we limit controversial tourism to "all touristic endeavours that arouse controversy, provoke discussions and conflicts, instigate discrepant 
opinions and are mostly evaluated negatively" (Stasiak, 2015). Criticism which may arise in connection to these types of tourist behaviour can be legal, ethical, cultural, social, aesthetic, economic or ecological.

This article aims to analyze a particular type of controversial tourism: the abuse of animals for tourism and sports purposes. The use of animals in the tourism industry dates back to the very beginning of tourism, for instance in zoos, oceanaria, dolphinaria or during safari trips. Millions of animals are used annually in the tourism industry as captives for shows and entertainment, as porters and carriers, as quarry to be hunted and fished, as well as for the purposes of competition and sports (Fennell, 2013). Together with a rising awareness of the necessity to develop sustainable tourism, growing attention has been paid to the fate of animals. Activists insist that visitors who come to areas where wild animals live should be admitted only if they are driven by educational purposes. Social media are swamped with campaigns against holiday souvenirs made of endangered species and with appeals for donations needed to enhance wild animals' quality of life. Researchers estimate that between 230,000 and 550,000 animals are being used in attractions that have a detrimental effect on their welfare. In contrast, only 1,500 to 13,000 animals are likely to be treated in a way that has a beneficial effect on their wellbeing and preservation. An analysis of the comments from tourist visitors concerning animalrelated attractions given on TripAdvisor shows that $80 \%$ of visitors did not recognize the problem nor were open to the welfare status of the animals (Moorhouse, Dahlsjo, Baker, D'Cruze, Macdonald, 2015).

This paper's contribution is to shed light on controversial animal tourism from a cultural and intercultural point of view since this is an underestimated aspect which has rarely been brought up by tourism, sports and leisure researchers. To begin with, the analysis of the problem will focus on the tourism supply side by presenting an overall thematic classification of controversial animal attractions and events which have their roots in local culture. Next, the causes will be considered from the point of view of the tourist demand side by placing controversial animal tourism in the context of both cultural omnivorousness and ethnocentric thinking about the relationship between humans and animals. Finally, a suggestion will be given on the development of responsible animal tourism as a possible solution.

\section{RESEARCH METHODOLOGY}

The article is based on both descriptive and analytical approaches to the issue. The case studies of controversial animal attractions have been collected by means of qualitative desk research from written and digital sources. Then selected by relevance and classified into thematic categories and subcategories.

\section{ANIMAL TOURISM: A CLASSIFICATION OF CONTROVERSIAL ATTRACTIONS AND EVENTS}

\subsection{ANIMALS IN CONTESTS}

\subsubsection{Animals in contests against animals}

Cockfighting has an important place within Balinese culture and a lot of holidays and festivities on the Indonesian island begin with this old tradition. The birds take part in a religious cleansing ritual in which a bloody sacrifice is given to the spirits. What seems cruel to foreign spectators is daily practice for the Balinese (Geertz, 2005).

Camel wrestling is a long-standing tradition upheld mostly on the Aegean coast of Turkey during the winter months from January to March, for this is the mating season for camels, and is as important as bullfighting in Spain. Their natural aggressiveness during this period is used to train the animals to fight with their feet and heads. Current law limits camel activity to one fight daily and this is supposed to prevent death and serious injuries (Sawala, Krawczyk, Bednarski, 2005).

One of the most popular pastimes in Ireland is dog racing, especially greyhound racing in which dogs chase an artificial hare. In many countries hunting with greyhounds is forbidden, while the popularity of this sport is high in Ireland. For the Irish, dog races are a peculiar element of their national culture (Zemsta 2008). However, this discipline has many opponents. Animal rights activists argue that it is a purely commercial business because dogs are treated like moneymaking machines. In addition, the greyhounds, due to their speed, do not have good manoeuvrability at a gallop, which means that the animals often crash into the fences while taking sharp bends. Opponents of the races also criticize the numerous cases of negligence or injuries, and the killing of greyhounds that are no longer capable of taking part. Although there seems to be a heightened sense of public contempt in many countries towards the cruel treatment of animals such as dogs in sports, the ways in which racing greyhounds are mistreated continue to be disregarded in academic research (Atkinson, Young, 2005).

The same goes for blood sports implying abuse, suffering and neglect of animals. In most western countries dog fighting is forbidden. However, this does not stop the organization of illegal dog fighting matches where 
the dogs fight on behalf of their owners. In Europe illegal dog fights take place in Germany, France, Italy, Great Britain and Russia. The USA is notorious as well for illegal dogfights which take place in nearly every state. It is a global problem as in many regions of Latin America, Africa, the Middle East and Asia, such fights are not only very popular, but also legal (Pierko, 2014).

\subsubsection{Animals in contests against men}

As a national sport bullfighting (corrida de toros) is one of the basic elements of Spanish identity. It is not only deeply rooted in Spanish culture, but also an integral part of the tourist imagination related to Spain. This tradition arouses controversy worldwide and in Spain itself because of the torturing of the bulls. Held in Pamplona, the traditional event of San Fermin consists in humans running in front of a group of bulls through the streets of the inner city. Prior to the event, the bulls are sedated so they are hurt when falling and are confused by the noise. Later they die, killed by a bullfighter. It can be estimated that approximately fifty bulls die yearly during the festivities, which is a huge number killed purely for fun.

La Rapa das Bestas is a festival of horse wrestling organized in Galicia. At the celebration, young people from Sabucedo head for the mountains at dawn. Their aim is to find the wild horses living in the area, drive them to the village and cut their manes, which leads to body-tobody fights between human and animal. Each year, the Rapa das Bestas festival attracts more and more visitors because of the spectacular nature of the battle between man and beast. In 1963 the event received the title of Fiesta de Interes Turistico Nacional in Spain, and in 2007 of Fiesta de Interes Turistico Internacional. The Galician people are very proud of this event as it is a symbolic ancient tradition. However, the feast is not a source of pride for everyone because it is detrimental to the wellbeing of the horses. Animal rights activists and ecologists far beyond the borders of the country publicly criticize the catching of wild horses and the cutting of their manes and tails (Buczkowska, Malchrowicz, 2010).

\subsubsection{Animals in contests between men}

Even events registered on the UNESCO List of Intangible Cultural Heritage arouse controversy such as camel polo, a team game played mostly in Mongolia. Tournaments are held by the Mongolian Camel Federation founded in 2002. The federation promotes the game through competitions among which the Naadam Festival, a traditional sporting event yearly organized during one of the main holidays in Mongolia. Ecologists claim, though, that camel polo may cause harm to the animals involved because they may be hit when players score goals (Lipoński, 2001).
An even worse case is the participation of children in sporting competitions involving camels in the Middle East which leads to serious injuries caused by the lack of observance of basic health and safety regulations (witness badly fitted caps). For years, thousands of minors from Pakistan and Bangladesh were sold by poor families to traffickers who sent them to the United Arab Emirates and Saudi Arabia where camel polo is extremely popular. Camel owners preferred to hire young children as they allegedly let the animals run faster. According to children's rights activists, many boys fell during high-speed races and suffered longterm injuries. Some children were trampled to death. The use of child jockeys was banned in 2005. Before that, approximately 3,000 children had been forced to work in this way. Asian children sold into slavery as camel racers received compensation from the United Arab Emirates for the injuries they had suffered. Nevertheless, some of them are still struggling with the indignity and the abuse they have experienced (Races in United Arab Emirates..., 2010).

Negative associations are also brought to mind by the Velká pardubická in the Czech Republic or the Tuscan Palio horse race in Siena because these events are very hard on animals. Velká pardubická is considered as the most difficult cross-country steeplechase run in Europe (Jastrzębska, Gugołek, Strychalski, 2017).

\subsection{ANIMAL SLAUGHTER}

\subsubsection{Animals as religious sacrifices}

In Nepal, until a few years ago, one of the most controversial events was a sacrificial ceremony called Gandhimai. The festival is partly financed by the Nepalese government, however tourists also add their contribution by paying entrance and parking fees. Millions of people from India and Nepal take part in the festival in honour of the Gandhimai goddess who is thought to fulfil their wishes if they sacrifice animals. Participants believe the ritual will bring them happiness and prosperity. In spite of the campaign against the festivities in 2014, nearly half a million animals were slaughtered that year: buffaloes, goats and young doves. Animal rights activists addressed the president of Nepal to end the abomination of killing animals which has lasted for 250 years. As a result, in $2015 \mathrm{Nepal}^{\prime}$ s temple trust cancelled all animal sacrifices at the festival (Compassion in world farming, 2019).

\subsubsection{Animals as hunting prey}

Every now and then the European media speak about the traditional slaughter of dolphins held yearly by Japanese fishermen. These reports are usually 
accompanied by vociferous opposition and the shock caused by "Asian barbarism". One should, however, notice that similar practices also happen on the Danish Faroes in the form of slaughtering pilot whales. Once the inhabitants begin their traditional hunt, coastal waters literally turn red. The hunt of pilot whales, mammals from the cetacean family, is usually held in summer and dates back several hundred years. During the hunt, pilot whales are herded towards the beach or fiord, dragged out and slaughtered on the sand. Surprisingly, the whole procedure has been legally regulated. For instance, Faroe Islander law specifically indicates which tools fishermen can use to kill the animals. The hunt has been criticized for years by animal rights activists who underline that the inhabitants no longer need to consume the whales' meat or fat, so the cruel hunt is thoroughly unnecessary. Those who practise the tradition argue that it is an inseparable element of Faroese culture, especially its culinary heritage. They also claim to kill pilot whales in a humanitarian manner and not to use the hunt for commercial purposes as most of the meat is not sold to local stores or exported, but distributed among the islanders. Meanwhile, the hunt has become an attractive event for tourists (Baliszewski, 2014).

\subsection{ANIMALS AS TOURIST COMMODITIES}

\subsubsection{Animals as means of transport}

In Southeast Asia elephants are commonly used as a traditional means of transport for tourists. Tourists who decide to visit the Cambodian temple and enjoy this form of entertainment usually do not realize that the elephants which work there have no access to water. In Cambodia in 2016, a female elephant which had been carrying tourists in the Angkor Wat temple for 15 years died of exhaustion. This accident shows that animals working in the tourism business are often subjected to a bad treatment and spend their lives suffering (Elephant dies..., 2016).

\subsubsection{Animals as circus attractions}

In South and Southeast Asia, the exploitation of elephants as tourist attractions is subject to many controversies. The phenomenon called phajaan (elephant crushing) is especially notorious. Phajaan is supposed to crush the elephant's spirit in order to domesticate it and place it under human control; it allegedly separates the spirit from the body of the animal. These elephants are later used in the tourism industry in Thailand, India and Cambodia. The process of phajaan starts with separating a baby elephant from its mother, already a traumatic experience as shown by the young animal's cries of despair. Next, it is put into a small cage which makes it impossible to lie down or to sit; the elephant is forced to stand still and is neither fed nor given water. "Trainers" prevent the elephant from sleeping by hitting its head, trunk and ears with primitive tools. Bamboo sticks covered with nails are hammered into the animal's skin, and its ears are torn apart. Once a 'shaman' states that the spirit has been separated from the body, the next step of the training begins. An elephant which has been subjected to physical punishment and locked in a cage will do anything to avoid this maltreatment which is encoded in its memory (Rizzolo, Bradshaw, 2018). As long as the elephant survives the torture, it is taught various tricks which are later presented to tourists to entertain them.

In Asian countries, one may come across an attraction called "elephant camps" in which these animals play football or make paintings. In Thailand, there are even - ethically questionable - art schools for elephants. The majority of tourists are not aware of the fact that elephants that they admire in the circus or watch in the streets while they are painting with their trunks, have most probably have undergone the process of phajaan. As long as tourists enjoy attractions and shows featuring elephants, these animals will continue to suffer. In order to inform tourists visiting Thailand about this practice, the Elephant Nature Park was founded in which elephants that experienced phajaan are taken care of (Elephant Nature Park, 2019; Rizzolo, Bradshaw, 2018).

\subsubsection{Animals as street attractions}

The tourism industry has been operating with snakes for many years. Snake charming is the practice of claiming to hypnotize a snake by playing an instrument. The dance these snakes perform is in reality a reactive sway to the snake charmer's movements as a means of self-defence from attack. The practice is most common in India, though other Asian countries are also home to snake performers, as are the North African countries of Egypt, Tunisia and Morocco. For tourism purposes, the snakes are captured and transported out of their natural habitats. Their teeth are removed, often without anaesthetic, their mouths are mostly sewn and partly shut, and their venom ducts are disabled by means of hot needles. A snake's life expectancy in this environment is much lower than the average. Lately, kissing the cobra has become an attraction on the street entertainment scene in Thailand. Cobras are captured and pinched with pliers, and their venom channels are blocked or removed with devices that can cause infections and even a painful death (Animals in tourism, 2017). 


\subsubsection{Animals as stuffed toys}

In recent years, the Tiger Temple in Thailand which attracts masses of tourists, has earned a bad reputation for mistreating animals and practising an illegal trade. The attraction is an extremely profitable source of money for the Wat Pa Luangta Bua Yannasampanno monastery whose yearly income reaches three million dollars. It is one of the rare places where humans can be in direct interaction with tigers. Tourists visiting the temple can feed, wash, and walk tigers while taking pictures; the animals can even be hugged or patted. Behind that cute image, however, there is serious harm to the tiger's well-being. Animal welfare campaigners and former temple workers claim the tigers are kept in tiny cages, improperly fed and given sedatives. Recently, opposition to this attraction increased when new details on animal abuse were published. Inside a huge refrigerator, dozens of dead cubs were found. Tiger births and deaths should be officially reported to the authorities, yet no such thing had been done for a long time, neither were the cubs seen around the temple. The monks were also blamed for illegally breeding, buying and selling the animals. Tigers belong to an endangered species according to wildlife protection acts and the Convention on International Trade in Endangered Species (CITES), a multilateral treaty signed by 183 parties, including Thailand, so the monks were violating international laws on nature protection. The Thai government was, hence, pushed to close the attraction and to move the tigers somewhere else, an unpopular decision as the legal intervention in a temple is a delicate matter in the Buddhist religious community (Nikt nie spodziewat się takiej tragedii..., 2016).

\subsubsection{Animals as tourist picture objects}

Selfies taken with animals are also an attractive extra for tourists. These pictures, however, are not only taken, for example, while sitting on an elephant. The use of wild animals as photographic objects is prevalent across the globe and is widely recognized to constitute a potential animal welfare concern (Carder et al., 2018) Misconduct of tourists towards animals is stimulated by their wish to share unusual photos on their social media accounts. An illustrative example is taking pictures with llamas which is a popular practice in Peru. This is not an easy thing to do because up in the mountains their natural behaviour is to run away from people. Peruvians, however, have found a way to meet tourists' expectations and to make some money. They walk decorated llamas, baby llamas and alpacas down the streets of the capital Cuzco while offering the opportunity for tourists to take pictures for money. However, llamas' natural habitat is pasture, not crowded streets.
In other countries, like Morocco or Israel, goats in trees are a local tourist attraction for taking pictures. Goats have an instinct to climb trees in search of leaves and nuts as it allows them to survive the harsh desert conditions. Nevertheless, some of these animals are forced to stay on trees for hours, looking nervously at the locals standing nearby who make sure the goats do not climb down so that tourists have the opportunity to make a selfie with the animals.

Tourists also love taking pictures with dressed up monkeys. In the majority of Asian countries the phenomenon of monkeys humanized for tourists' amusement can be found. Fully dressed monkeys take part in parades or talent shows, they even serve drinks in local pubs. In India, it is widely popular to demonstrate to tourists the arcana of taming and training monkeys. Most monkeys trained for tourist shows have been captured in the jungle and, probably, taken away from their relatives. The animals are taught a few tricks, such as greeting pedestrians, dancing or performing acrobatic tours for money. Monkeys are extremely intelligent, hence teaching them unconditional obedience can only be achieved by means of torture. The animals are beaten and starved in order to make them obey their owners' orders and their teeth are extracted so that they are not able to bite in self-defence. Interestingly, such activities have been forbidden by Indian law for years, yet the application of the legal rules is very faulty.

Carder et al. (2018) investigated how brown-throated three-toed sloths were handled by tourists, and how these slow-moving mammals behaved during wildlife selfie sessions of tourists in Brazil and Peru. Research results show that, when handled, sloths were frequently held in ways that could compromise their welfare. To date the behaviour of these sloths has not been dealt with in the academic literature, certain behaviours documented by Carder et al. (2018) can certainly be interpreted as symptomatic of the physical suffering endured by the animals.

\subsubsection{Animals as tourist food}

During the month-long "celebration" of the annual Dog Meat Festival in China, thousands of dogs are slaughtered. It is often the case that dogs are kidnapped from their owners so that they can be used. Terrified and kept in cages, the animals wait to be killed. Dog meat lovers use blunt sticks to hit the animals and watch them bleed to death. Next, the dogs are put on hooks, disembowelled, skinned and sold as a culinary treat. Scientists claim that the canine brain is fully capable of experiencing emotions, hence the torture that the dogs experience during the festival must be heavy. It could be suggested that international public opinion can push the Chinese to abandon this tradition, yet deep-rooted 
cultural habits can only be changed gradually, which takes years (Zemsta, 2008).

Extraordinary dishes are often prepared by using endangered species. Usually, local communities cannot afford this food, even though it constitutes part of their gastronomic tradition. This kind of phenomenon can be observed in some parts of Portugal where a rare crustacean, the goose barnacle (percebe in Portuguese) lives. The crustaceans can be found only in Portugal, Galicia, Brittany, and Morocco. They look like pointed shells with a protruding 'leg' which is the edible part to be cooked in seawater. The freshest barnacles are served in Alentejo, Portugal, in local restaurants called percebeiros. Barnacles are expensive for one crustacean does not provide much that is edible. Besides, the animals live in hard-to-reach colonies on coastal rocks which are strictly guarded family secrets and in the poor regions of Portugal, there are families who make a living by collecting them. Officially, this practice is prohibited as it might lead to destroying whole colonies and it causes danger for the collectors. Nevertheless, due to tourists, there is an increasing interest in goose barnacles and their prices have become exorbitant. National regulations and potential danger do not discourage illegal collectors. Hence, the controversy here is twofold. Firstly, as tourists wish to consume the barnacles, there is a risk of extinction; secondly, locals who collect barnacles for tourist restaurants endanger their health and even lives. Moreover, tourists participate in the process of collecting barnacles driven by the wish to learn more about the local culinary heritage and to take part in gathering local food. This so-called foraging tourism is a variant of creative tourism, a niche within the cultural tourism market that is rapidly developing due to a tourist's need for experience in the form of educative interaction with the culture, nature and landscape of the destination. Richards and Wilson (2006) define creative tourism as a type of tourism which offers visitors the opportunity to develop their creative potential through active participation on courses and learning experiences which are characteristic of the holiday destination where they are undertaken.

\section{THE IMPACT OF CULTURAL OMNIVOROUSNESS ON CONTROVERSIAL ANIMAL TOURISM}

Up to now tourism research has neglected cultural omnivorousness as a factor which can help to explain the attitude of tourists towards the abuse of animals in the tourism industry. In this section how cultural omnivorousness contributes to keeping alive controversial forms of animal tourism, that are closely linked to (inter) cultural tourism, will be argued.
There is a rapidly growing body of literature defining and discussing cultural omnivorousness from a sociological point of view. Peterson (1992) proposed the term "cultural omnivore" to address the phenomenon of people of higher social status enjoying participation in activities associated with popular culture. A decade later, Holbrook, Weiss and Habich (2002) confirmed the emergence of a category of consumer who like to spend their leisure time on a wide range of cultural activities. In line with this, Warde, Wright and Gayo-Cal (2007) describe cultural omnivorousness as a trend in western society for the experience of a wide variety of forms of culture. By characterizing omnivorous cultural consumers as those with an extremely varied cultural taste who enjoy crossing the borders between high and low culture, Bauman (2011) not only retakes the definition of Peterson (1992), but confirms at the same time its permanence of which Peterson discerned the first contours twenty years earlier. The scope of omnivorous cultural consumption is broad, covering areas like culinary tastes, interests in music and engagement in sports. The term is now a crucial element within modern cultural theory, and a heated debate on the connection between a person's socioeconomic status and cultural taste is ongoing. Furthermore, the question arises whether cultural omnivorousness encourages tolerance and cultural integration (Karademir-Hazir, 2015; Warde, Wright i Gayo-Cal, 2007).

Cultural omnivorousness has stimulated to a considerable degree the development of cultural tourism (Richards, 2002, 2013). Research has clearly shown the causal relationship between cultural omnivorousness, and participation in cultural events, visiting cultural sites and discovering exotic cultures (Toivonen, 2019). The behaviour of the contemporary cultural tourist seems increasingly not to match the label attached to the standard cultural tourist. The $21^{\text {st }}$ century cultural tourist is more likely to look for cultural experiences which meet very specific cultural wants and needs. The development of the 'zap culture' has stimulated the rise of the omnivorous cultural tourist, who undertakes a growing diversity of leisure activities and consumes both high and popular culture with equal ease. This trend away from general to more individualized patterns of cultural consumption is an evident feature of the postmodern leisure market characterized by a hunger for new experiences. Suppliers of leisure experiences have reacted to the development of this Erlebniskultur (experience culture) by combining different types of experiences in their products (Richards, 2003). Omnivorous cultural tourists are the most typical representatives of 'post-tourism'. This term was introduced by Feifer (1985) and then adopted by Urry (1990) and Rojek (Rojek, Urry, 1997), created in order to analyze the new consumer tourist attitudes observed in the postmodern era and which are influenced by 
such phenomena as globalization, hyper-consumption, the experience industry, and the development of new technologies.

There is a general perception that cultural tourism is good as it attracts high-spending visitors and causes little damage to the environment or local culture while contributing a great deal to the economy and the preservation of culture (Buczkowska, Malchrowicz-Mośko, 2012). However, researchers have noticed that cultural tourism may do more harm than good, inciting the cultural tourist to penetrate sensitive cultural environments as an advance guard of mass tourism (Richards, 2003). Basically, controversial animal tourism originates in the need for $21^{\text {st }}$ century cultural travellers from wealthy countries to visit exotic destinations and, as they believe, "undiscovered" cultures. This cultural omnivorousness makes tourists sensation-seeking, which contributes to the rise, development and perpetuation of controversial forms of tourism such as the abuse of animals featuring in tourist attractions or cultural and sports events. It is for the needs of these tourists that events with the participation of animals in many developing countries around the world are given. As typical representatives of contemporary consumer-centred societies, they want to experience unusual and exciting holiday adventures which they may boast about to impress those in their own social environment with a view of increasing their social prestige, distinguishing themselves from others, and developing a special identity.

Interestingly, omnivorousness in the figurative, cultural sense may contribute to culinary omnivorousness in the literal, physical sense. As one of the main forms of cultural tourism, culinary tourism has characteristics - what, when, where, how and with whom we eat-which are determined by natural, cultural, religious and medical factors. Food consumption serves as a basis for human relationships as it constitutes a bonding ritual and contributes to closeness. Food can also be interpreted as an indicator of status: the higher the social status, the more variety on the menu, meeting the desire to try rare and exotic dishes. In other words, groups of a higher social status are more willing to taste unknown food, which leads to culinary omnivorousness. The increasing need to experiment with new dishes explains the dynamic growth of culinary tourism, often characterized by snobbery, ostentatious consumption and a desire for social prestige and distinction (Konopczyński, 2016). A very special category of culinary tourists are those who tend to choose exotic destinations where they can try unusual dishes and, in this way, upgrade their social status. Eating dog meat like Chinese people do constitutes a taboo subject for Europeans. Culinary taboos are a conscious ban on consuming specific food which is, nevertheless, edible in terms of digestion. Tourists who take part in the Chinese Dog Meat Festival consciously break a culinary taboo and as a part of their holiday adventures abroad, this meaningful act contributes to the prestige of the performer. Eating hard-to-reach dishes is a clear instance of cultural and culinary omnivorousness going hand in hand and leading to the risk of extinction of endangered species such as Portuguese goose barnacles.

\section{THE PITFALL OF WESTERN ETHNOCENTRISM}

The preceding descriptive analysis of controversial animal tourism may be described as unicultural because it is focused on the western point of view. Hence, it is worthwhile supplementing it with an intercultural approach based on comparison and the bridging of differences between cultures. Contacts between the international tourist as a guest and the local population as a host community are encounters between cultures. Similarities and differences in cultural background determine the social interaction. If there is a difference in norms, values and rules of conduct between the tourist and the local population, there is the potential risk of a collision between the two cultural patterns. This collision is due to the natural phenomenon that members of a culture consider customs taught by their parents and ancestors as good and beneficial, and respect the social norms and rituals transmitted by tradition. People are submitted to the natural inclination to look at the foreign culture from their specific background and to regard their own traditions, beliefs and values as superior to others, an attitude known as ethnocentrism. This problem particularly applies to intercontinental tourism (Reisinger, Turner, 2003).

When it comes to the problem of using animals in tourism, representatives of western cultures very often describe these practices as unethical, inhuman and barbaric from an ethnocentric point of view. It should be highlighted, however, that local communities have different attitudes to animal welfare: for most of them, animals are simply economic resources to be used. Animal rights are not the top concern of local people in many developing countries, who are often extremely poor and are simply trying to make a living. As tourists bring in money, they contribute to maintaining an extensive supply of controversial attractions or cultural and sports events with a long history and tradition which put animals at risk for entertainment. In addition it is necessary to recognize that Westerners are heirs of many cultural practices that cause suffering to animals. The examples of controversial tourism in Europe and the United States of America presented in the first section demonstrate that similar phenomena happen in western cultural communities too. Hence, 
a certain level of cultural relativism is required, especially when we look at the history of western thinking about the relationship between humans and animals which will help to explain the origins of their present mistreatment in western societies.

Ancient western philosophy did not distinguish itself when it came to standing up for the wellbeing of animals. Aristotle played a very important role in proclaiming the idea of man's superiority. In his work Politics (Arystoteles, 1964), he is one of the first thinkers to state that animals are deprived of reason, which determines their inferiority and subordination. In his opinion, animals only serve human needs just like vegetation serves the needs of animals. These needs are, for example, clothing and food. As Vardy and Grosch (1996) notice, the Christian tradition was inclined to follow the views of Aristotle. Saint Augustine attests that animals, being deprived of reason, are not at the same moral level as humans which is why people can do anything with them and whatever they want. Thomas Aquinas expresses views similar to those of Saint Augustine, if even more emphatically. In his work Summa theologiae, he argues that it is not important how man deals with animals because God subjected all earthly things to human rule. Furthermore, God does not care for animals and does not ask people to account for what is done to animals. Although Descartes did much to free philosophy from theological ties, he alleged that animals can be experimented with at will because they cannot experience pain (1984). Descartes's views are shared by Kant in his Metaphysics of Morals (1984). He believes that when it comes to animals, humans do not have any duties as animals are deprived of self-awareness, they are only a means to the end, and this end is human. It can be concluded that for a very long-time western thinkers were convinced that the relationship between human and animal was not subject to ethical considerations because animals are creatures without reason. This was the justification for an almost absolute permission for humans to do what they liked with animals.

Today, however, more and more western people have become aware of the harm humans can cause to animals by making them suffer. Animal activists argue that humans should not do what they like with animals: inflicting unnecessary pain degrades us as moral beings (Vardy, Grosch, 1996). Probably, the broadest definition of animal activism would describe it as an effort to defend the interests of animals and to intervene in any social, political, economic, or environmental area where it is necessary to improve their coexistence. In recent years, this change in the western attitude towards animals has also been reflected in the growth of the interdisciplinary field of animal studies. Animal studies are basically inspired by so-called post-humanism, relying on the principle that the world does not have to be perceived and organized in such a way as to secure only the interests of humans, and that also applies to tourism (Wolfe, 2013).

\section{CONCLUSION: TOWARDS A RESPONSIBLE ANIMAL TOURISM}

The need for solutions to the current environmental crisis has never been greater (Mastrangelo, Aguiar, 2019) and the ecological modernization theory has recently grown in importance. Ecological modernization is a school of thought in the social sciences that argues that the economy benefits from moves towards environmentalism (Hajer, 1995). As farm animal welfare in particular has become an increasingly important component of contemporary global livestock production, animal welfare science and animal welfare policymaking need to find new ways of entering global debates on food security and sustainability (Buller, Blokhuis, Jensen, Keeling, 2018). Therefore, sustainability is also an important topic for animal tourism. Analysis of controversial animal tourism supply shows that the abuse of animals for the needs of cultural tourism occurs in all continents. The persistence of the phenomenon is due to a significant extent to cultural omnivorousness which incites tourists to eagerly enjoy animal attractions and cultural events during their travel. Can traditions be a justification for treating animals in a bad way? Would some cultural rituals involving animals still be in their current forms if they were not attractive to tourists? How to prevent the need for novel and sensational cultural experiences resulting in highly controversial tourist conduct? Such questions are raised by animal activists as well as animal studies scholars who claim nature does not necessarily exist to satisfy the needs and wants of humans only. Both are looking for solutions which might serve as arguments in a cross-cultural discourse on how to behave towards animals while taking into consideration both animal welfare and local needs. It is to be feared that faced with a growing demand for shocking attractions the tourism industry will offer more and more controversial products related to animal tourism unless NGOs, such as animal welfare organizations, backed by the outcomes of research on animal tourism, succeed in creating awareness about existing bad practices among all involved parties. These efforts may benefit from the attention and care for sustainability in tourism shared by more and more of the key actors involved, tour operators as well as local suppliers and policymakers. Responsible and sustainable animal tourism expresses itself by avoiding destinations involving the abuse of animals, endeavours to stop the exploitation of animals in the tourism industry, and donating 
money to various organizations and charities aimed at improving animal welfare.

In the tourism business, like in any kind of commercial industry, demand usually creates supply. Hence, it is crucial that above all tourists should be made aware of the rights of animals to welfare. Despite the increasing awareness of animal welfare issues, many tourists still do not realize the impact of their conduct on animals at the destinations they visit. More than bans and sanctions, an appropriate way to improve animal quality of life in the tourism industry seems to be effective information and education on the negative impact that tourist consumer behaviour may have. Tourists should be taught to take responsibility to ensure that their holiday is sustainable not only by benefiting local host communities from their stay, and by protecting the environment, but also by contributing to animal welfare. The Elephant Nature Park in Northern Thailand where elephants that have endured phajaan are kept can serve as a best practice of tourist education to be followed. In this respect, the tourism industry too has a crucial role to play by informing their customers about animal rights and welfare and by making them aware of theirindividual responsibility. Asa part of a company's sustainability policy, managers should develop and observe guidelines based on the "Five Freedoms" for animals: freedom from hunger or thirst; freedom from discomfort; freedom from pain, injury or disease; freedom to express normal behavior; freedom from fear and distress (see Thomas Cook, 2019). More general$l y$, these freedoms may serve as pillars of responsible animal tourism and as an effective weapon in the battle against its controversial counterpart. They can also be used as a background for further quantitative and qualitative field research, involving managers and visitors to animal attractions, in order to broaden the theoretical perspective.

\section{REFERENCES}

Animals in tourism (2017). Retrieved from: https://www.tourismconcern.org.uk/wp-content/uploads/2018/03/Animals-inTourism-lWeb-FINAL-1.pdf (20.08.2019).

Arystoteles (1964). Polityka. Translated by L. Piotrowicz. Warsaw: PWN.

Atkinson, M., Young, K. (2005). Reservoir dogs: Greyhound racing, mimesis and sports-related violence. International Review for the Sociology of Sport, 40 (3), 335-356. DOI: https://doi. org/10.1177/1012690205059953

Baliszewski, T. (2014). Tradycyjna rzeź delfinów także w Europie. Morze staje sięczerwone od krwi... Retrieved from: https://natemat.pl/89979, tradycyjna-rzez-delfinow-takze-w-europie-morzestaje-sie-czerwone-od-krwi (5.11.2019).

Bauman, Z. (2011). Kultura w płynnej nowoczesności. Warsaw: Agora.

Buczkowska, K., Malchrowicz, E. (2010). Fiesty hiszpańskie -jeszcze święta lokalne, czy już tylko atrakcje dla turystów? Turystyka Kulturowa, 4, 17-47.
Buczkowska, K., Malchrowicz-Mośko, E. (2012). Cultural tourism ethical dilemmas. Cultural Tourism, 12, 78-91.

Buller, H., Blokhuis, H., Jensen, P., Keeling, L. (2018). Towards farm animal welfare and sustainability. Animals, 8 (6). DOI: https://doi.org/10.3390/ani8060081

Carder, G., Plese, T., Machado, F., Paterson, S., Matthews, N., McAnea, L., D'Cruze, N. (2018). The impact of selfie tourism on the behaviour and welfare of brown-throated three-toed sloths. Sustainability, 8 (11), 216. DOI: https://doi.org/10.3390/ ani8110216

Compassion in world farming (2019). Retrieved from: www.ciwf. $\mathrm{pl}$ (7.10.2019).

Elephant dies from exhaustion after decades carrying tourists to Cambodia's Angkor Wat (2016). Retrieved from: https://www. independent.co.uk/news/world/asia/cambodia-elephant-dies-exhaustion-decades-carrying-tourists-to-angkor-wat-a6999851.html (2.09.2019).

Elephant Nature Park (2019). Retrieved from: www.elephantnaturepark.org (15.09.2019).

Feifer, M. (1985). Going places. London: Macmillan.

Fennell, D. (2013). Tourism and animal welfare. Tourism Recreation Research, 38 (3), 325-340. DOI: https://doi.org/10.1080/0250828 1.2013.11081757

Geertz, C. (2005). Głęboka gra - walki kogutów na Bali. In: L. Kolankiewicz (ed.), Antropologia widowisk. Warsaw: Uniwersytet Warszawski.

Hajer, M.A. (1995). The politics of environmental discourse: Ecological modernization and the policy process. Oxford: Oxford University Press.

Holbrook, M.B., Weiss, M.J., Habich, J. (2002). Disentangling effacement, omnivore and distinction effects on the consumption of cultural activities: An illustration. Marketing Letters, 13, 345-357.

Jastrzębska, A., Gugołek, A., Strychalski, J. (2017). Zwierzęta w sporcie, rekreacji i rozrywce. Wiadomości Zootechniczne, LV, 87-93.

Kant, I. (1984). Uzasadnienie metafizyki moralności. Translated by M. Wartenberg. Warsaw: PWN.

Karademir-Hazir, I. (2015). Cultural Omnivorousness. Sociology. DOI: https://dx.doi.org/10.1093/obo/9780199756384-0134

Konopczyński, F. (2016). Smaki Polaków. Możliwości, gusta, pragnienia. Retrieved from: www.malakulturawspolczesna.org/2016/12/10/ filip-konopczynski-smaki-polakow-mozliwosci-gusta-pragnienia/ (5.10.2019).

Lipoński, W. (2001). Encyklopedia sportów świata. Poznań: Atena.

Mastrangelo, M.A., Aguiar, S. (2019). Are ecological modernization narratives useful for understanding and steering socialecological change in the Argentine Chaco? Sustainability, 11 (13). DOI: https://doi.org/10.3390/su11133593

Moorhouse, T.P., Dahlsjö, C., Baker, S., D'Cruze, N., Macdonald, D. (2015). The customer isn't always right: Conservation and animal welfare implications of the increasing demand for wildlife tourism. PLOS ONE, 10 (10). DOI: https://doi.org/10.1371/ journal.pone.0138939

Nikt nie spodziewat się takiej tragedii. Horror w Światyni Tygrysów (2016). Retrieved from: https://www.national-geographic.pl./ aktualnosci/nikt-nie-spodziewal-sie-takiej-tragedii-horror-w-swiatyni-tygrysow-uwaga-drastyczne (15.09.2019).

Peterson, R. (1992). Understanding audience segmentation: From elite and mass to omnivore and univore. Poetics, 21, 243-258. DOI: https://doi.org/10.1016/0304-422X(92)90008-Q

Pierko, M. (2014). Historia niehumanitarna - nielegalne walki psów na świecie $i w$ Polsce. Retrieved from: www.naszpies.com/tutorials/article/35-historia-niehumanitarna---nielegalne-walki-psow-na-swiecie-i-w-polsce/ (12.11.2019).

Pine, J., Gilmore, J. (2011). The experience economy. Brighton: Harvard Business Review Press. 
Races in United Arab Emirates 'breaking ban on child camel jockeys' (2010). Retrieved from: https://www.telegraph.co.uk/news/ worldnews/middleeast/unitedarabemirates/7356558/Races-inUnited-Arab-Emirates-breaking-ban-on-child-camel-jockeys. html (10.09.2019).

Reisinger, Y., Turner, L.W. (2003). Cross-cultural behaviour in Tourism. concepts and analysis. Oxford: Butterworth-Heinemann.

Richards, G. (2002). Postmodernity and cultural tourism. Conference materials from Cultural Tourism-Future Trends, Valladolid.

Richards, G. (2003). What is cultural tourism? In: A. van Maaren (ed.), Erfgoed voor toerisme. Amsterdam: Nationaal Contact Monumenten.

Richards, G. (2013). Cultural tourism. In: T. Blackshaw (ed.), The Routledge handbook of leisure studies. Oxon: Routledge.

Richards, G., Wilson, J. (2006). Developing creativity in tourist experiences: A solution to the serial reproduction of culture? Tourism Management, 27 (6), 1209-1223. DOI: https://doi. org/10.1016/j.tourman.2005.06.002

Rizzolo, J.B., Bradshaw, G.A. (2018). Human leisure / Elephant breakdown: Impacts of tourism on Asian elephants. In: N. Carr, J. Young (eds), Wild animals and leisure. Oxon: Routledge.

Rojek, Ch., Urry, J. (1997). Touring cultures. London, New York: Routledge.

Sawala, K., Krawczyk, W., Bednarski, J. (2005). Wielkie fiesty Europy. Przewodnik etnoturystyczny. Poznań: Atena.
Schulze, G. (1992). Die Erlebnizgesellschaft. Kultursoziologie der Gegenwart. Frankfurt am Main: Campus-Verlag.

Stasiak, A. (2015). Turystyka kontrowersyjna jako przejaw gospodarki doświadczeń. In: G. Godlewski (ed.), Turystyka kontrowersyjna na współczesnym rynku podróży. Biała Podlaska: AWF.

Thomas Cook (2019). Retrieved from: www.thomascook.com (5.08.2019).

Toivonen, T. (2019). Omnivorousness in cultural tourism: An international comparison. Retrieved from: http://www.tram-research. com/atlas/timotoivonen.PDF (11.10.2019).

Urry, J. (1990). The tourist gaze: Leisure and travel in contemporary societies. London: SAGE Publications.

Vardy, P., Grosch, J. (1996). Ethics. Warsaw: Zysk i S-ka.

Warde, A., Wright, D., Gayo-Cal, M. (2007). Understanding cultural omnivorousness: Or, the myth of the cultural omnivor. Cultural Sociology, 1 (2), 143-164. DOI: https://doi. org/10.1177/1749975507078185

Wolfe, C. (2013). Animals studies, dyscyplinarność i (post)humanizm. Teksty Drugie, 1-2, 125-153.

Zemsta, M. (2008). Świat festiwali. Warsaw: National Geographic.

Article received:

10 October 2019

Accepted:

2 April 2020 